\title{
Research on the reform and innovation of campus ideological and Political Education under the background of big data
}

\author{
Gaochao Chen ${ }^{1, a}$ \\ ${ }^{1}$ Jiangxi Vocational technical College of Industry \&Trade,jiangxi,nanchang,330038 \\ a739960103@qq.com
}

\begin{abstract}
:
In the context of the new era, the reform and innovation of Ideological and political education in Colleges and universities should keep pace with the times, and promote the combination of the traditional advantages of Ideological and political education and new science and technology. Based on the all-round effect of data and information on the ideological and political education in Colleges and universities, this paper proposes the application of big data technology to promote the innovation of Ideological and political education in Colleges and universities from the perspectives of data creation, ability creation, role transformation and means innovation. Since entering the 21 st century, the application of big data technology to the innovation and upgrading of Ideological and political education in Colleges and universities has gradually become a hot topic in the academic circles.
\end{abstract}

Key words: big data background; Ideological and political education; Reform and innovation

\section{大数据背景下校园思政教育改革与创新研究}

\author{
陈高超 $1, \mathrm{a}$
}

\author{
${ }^{1}$ 江西工业贸易职业技术学院 江西 南昌 330038 \\ ${ }^{a} 739960103 @ q q . c o m$
}

摘 要:

在新时代的背景下, 对高校的思政教育工作进行改革创新, 应该要与时俱进, 促进思政教育工作的传统优点 和新型科学技术相结合。本篇文章就数据信息对于高校思政教育工作产生了全方面作用为基础, 凭借数据创 建、能力创建、角色转变以及手段创新等多种角度, 倡议应用大数据技术推动高校思政教育工作创新的应对 措施。步入 21 世纪以来, 应用大数据技术对高校的思政教育工作进行创新升级, 已经逐渐成为学术界的探讨 热点。

关键词: 大数据背景; 思政教育; 改革与创新

\section{1. 大数据对高校思想政治教育的多维影响}

随着互联网科学技术的不断发展进步，网络对 于如今学生的学习与日常生活产生了巨大的影响, 并且就高校的思政教育工作而言，互联网技术产生 了覆盖化的打击和作用。

\section{1. 对思维方式的影响: 从 “因果性”思维 拓展到“相关性” 思维}

以往的思政教育教师，一般都是经过观察学生 的言行举止来判断寻找之中的因果关系, 从而探索 这种言行举止的思想表达。依据实际情况了解到, 只凭借三言两语，难以精准的确定其中的思想观念。 使用大数据技术寻找到了一种研究大学思想观念的 新型方式, 就是指经过数据新型和相关的机械设备, 
对于学生的日常生活和行为规范进行真实的记录和 整合，以数据信息为基础来发现规律性，进而分析 和探究大学生的思想观念和行为举止的特征和发展 趋势, 进而强化教育工作的预测性和准确性。固然, 使用这种方法进行 “相关性” 的统计，尽管拥有启 发性和预见性，然而也不可以其中基本的因果。换 言之, 大数据信息重视寻找其内涵, 反而难以讲述 原因。虽然如此, 以大数据的相关性逻辑为基础, 全方位的扩大了思政教育发展和实施的思想观念。

\section{2. 对教育过程的影响：从 “粗放” 发展到 “精准”}

根据心理学信息了解到, 每一种内在思想一定 会分化为各种言行举止, 并且大部分的言行举止信 息数据可以反应出自身的真实想法。大数据技术借 助自然环境下来篮选并保存教育对象的言行数据, 把握和推测教育对象的思想 “痕迹”，将教育过程从 静态转变为动态, 从模糊转向精确。首先, 借助大 数据可以时刻掌握大学生的实时工作、学习和生活 变化, 突破了人为观察的时间和地点限制。其次, 大数据可以提升对大学生思想动向的把握程度, 提 升教育的先进性。再次, 借助大数据的分析, 思想 政治教育可以针对学生的实际情况来制定, 实现针 对式教育。

\section{3. 对教育时空的影响: 从 “在场、共时” 走向 “在线、实时”}

传统思想政治教育工作地点大多固定在课堂或 者有形地域, 并且要和时间对应。给教育带来了很 大的束缚, 无法满足思想政治教育的 “润物细无声” 的需求。当前信息技术呈快速发展的趋势, 传统课 堂逐渐被 “在线教育” 取代, 有利于打造一个以学 生者为主体, 满足各类群体要求的专业教育资源学 习资源库学习系统。如今大学生使用移动智能手机 的频率越来越高, 网络可以作为教导大学生思想政 治教育的核心媒介, 大学生可以借助不同的微平台 来学习思想政治教育。在当前的教育背景下, 大数 据技术和平台既能给予不受时间和地点束缚的在线 交流媒介, 又能在交流时记录不同角度的数据, 从 而准确得把握学生的思想变化和规律, 将因材施教 的教育目标成为可能。

\section{4. 对主客体关系的影响: 从 “上对下教 导” 转变为 “主体间对话”}

教师在开展思政教学时会受到传统教学观念的 影响, 没有将学生作为课堂教学的主体, 而是将教 师作为课堂教学的主体, 不能充分发挥出引领和帮 助的价值。现阶段随着信息技术的不断发展, 我国 逐渐进入了大数据时代, 网络对于如今学生的学习 与日常生活产生了巨大的影响, 大数据使思政教育 的教学素材和教学内容产生了很大的变化。同时大
数据还改变了教师的教学理念, 使教师在开展思政 教学的过程中将学生作为课堂教学的主体。所以, 在大数据背景下，思想政治教育 “交互性” 特征较 突出。教育是一种主体之间对话的过程, 若思想政 治教育工作者不能做到对教师的考核和评价, 并且 不及时更新教育方式, 很有可能降低学生的学习兴 趣和热情。

\section{2. 以大数据驱动高校思想政治教育创新的现 实对策}

大数据在高校开展思政教育的过程中起着至关 重要的作用, 它不仅可以调整学校和教师的教学方 式和理念, 还可以促进课程机制不断革新发展。所 以, 高校需要认识到大数据的重要性, 充分发挥出 大数据的价值。

\section{1. 以 “依托与整合” 为切入, 完善 “数据 系统” 基础建设}

现阶段高校的网络建设水平正在不断提升, 但 学校在开展思政教育时还不能充分发挥出网络平台 的价值, 高校需要适当地依靠大数据来发展思政教 育。

第一要让数据做到 “留下来”。首先要认识到档 案信息的重要性, 通过不断收集相关数据来建立起 多样化的档案信息, 将学生的生活方式和学习方式 记录在档案里面, 以此来了解学生的心理变化和思 想观念; 其次要构建起完善、规范的思政教育数据 监督体系, 将与大学生思政学习相关的数据收集起 来, 从这些数据中选取出有效性较高的数据来储存 收藏, 然后通过网络技术来构建一个思政教育平台; 最后要创建一个与物联网传感器相关的数据收集平 台, 以此来提高高校在档案梳理和总结方面的能力, 使思政教育可以更加顺利地开展。

第二要让数据做到 “联起来”。高校需要建立起 严格的数据分类标准, 使相关工作人员了解数据的 标准统计形式和与数据相关的规则。在各个层次和 类型的数据中, 实现标准化、规范化和交互化, 保 证能够实现数据的按时更新、深度融合以及按需流 动, 借助接口技术以及规范化的数据建设, 来完成 对数据的整合。

第三要让数据做到 “用起来”。第一，把现存的 所有管理分析系统作为基础, 把思政教育的数据管 理以及数据分析系统进行 “嵌入”, 进一步拓宽所有 数据资源的途经, 在应用的时候, 提升有关数据的 活力, 充分调动大数据在深层应用方面的功效。第 二，应该进一步研究并借鉴现代的信息分析技术， 充分融合大学生思政教育的特征, 对大学生思想发 展趋势的预测技术、思想数据的统计分析技术以及 思想行为关联的挖掘技术等进行探索与开发，在大 
学生思想行为大数据内, 进行智能化、系统化的分 析、统计与预测。

\section{2. 以 “需求与问题” 为牵引, 提升思想政 治教育者的 “数据能力”}

在应用大数据对思政教育进行创新的时候，综 合提高数据的素养是其中的关键所在。高校思政教 育者在提高 “数据能力” 方面的关键性内容是充分 调动学生自主学习能力强的特征, 正确指导学生, 坚持把 “需求和问题” 作为牵引, 在应用大数据对 思政教育实践进行创新的过程中，逐渐形成较高的 运用和认识数据的能力。

第一，要进一步提升在数据思维方面的能力。 对大学生的思想进行分析, 既要合理应用定性的理 性思维, 同时也要正确运用 “数据思维”, 要学会用 数据说话, 并且运用数据来进行论证与分析。更加 具体的来讲, 即提升利用具体的、动态的以及生动 的数据来讲述道理的能力, 更好的利用数据发展的 态势, 对大学生思想行为发展趋势进行预测跟研究, 充分分析数据关联的性质，对不同事物之间相互关 联的情况进行探索。

第二是要增强数据转换水平。要想在大数据的 影响下了解大学生的实际思想和行动, 就要深刻考 虑学生在思想政治教育实践过程中产生的实际问题, 将在思想政治教育教学过程中的问题用相关的数据 分析方法解决。从教育者的角度来看, 为学生提供 良好的学习条件, 将晦涩难懂的事物用通俗易懂的 数据表达出来, 并从中探索和发现相关规律, 增强 学生对思想政治的理解和掌握程度, 同时还能增强 学校的教学质量。

\section{3. 以 “借鉴与改造” 为途径, 促进思想政 治教育的方法创新}

在开展思政教学的时候, 可以对其它领域在大 数据应用方面的经验进行借鉴与参考, 充分联系自 身实际发展状况, 实现完善和优化, 从而创新高效 在思政教育教学方面的措施。一方面, 在 “学习分 析技术” 的基础上, 增强对大学生思想的深层了解。 近几年，“学习分析技术” 在教育领域越来越受重视。 这个方法是在学生进入学习平台产生的数据的基础 上进行的, 并且对这些数据进行深度总结和分析, 进一步了解学生的学习情况。要想利用 “学习分析 技术” 来推动思想政治教育的完善和发展, 就要对 大学生在思想、行为举止等方面的情况进行重视和 分析, 主要了解大学生主要在做些什么? 他们的时 间分配是怎样的? 他们学到了什么? 等等相关情况。 另外, 利用对相关数据的搜集和深层度分析, 能够 进一步了解大学生的思想状况, 更好地开展思想政 治教学。
另外，使用 “数据挖掘技术” 来继续渗透思政 教育的思维方式。增强数据挖掘技术, 对学校政治 老师的专业能力有很高的要求。要跟上时代步伐, 重视当前的信息技术成果，把高新技术和学生思想 政治课堂内容相结合, 帮助学生利用信息技术来解 决思想政治方面的问题, 打开思维方式, 发挥信息 技术专业人才的引导作用，以提高思想政治教育成 果为目的, 分析当代大学生思维方式, 并且进行渗 透、帮助, 使心理研究、环境研究、语言研究能更 加科学化、高效化。建立知识渗透和提升学习成绩 的研究系统, 帮助老师们掌握学生学习情况。

\section{4. 以 “角色与定位” 为重点, 重构教育者 与被教育者的关系模式}

在落后的思想政治课堂里，老师占主要地位， 发挥教育引导、创造能力, 也是课堂的主人。随着 时代的发展, 这种方式不能帮助学生提高学习成绩, 要和信息技术时代一同发展, 创建全新的思想政治 课堂地位角色的新形势。

第一, 从教育者的角度进行改变。随着大数据 的不断推进, “扁平化” 是如今获取信息途径的特征, 在这样的情况下, 教育者和被教育者并没有什么区 别。所以, 要想改变这样的现状, 就要改变现有的 “上对下” 教学模式, 用 “互动交流” 角色教学模 式代替, 让教育者的任务是制定教育实践活动、研 究教育内容的研究人以及指导学生的前进方向, 并 不是去执行教学活动或者是传播教学内容, 也不是 去操控学生的思想和行动。

另外老师和学生之间的沟通方法也需要改进。 老师应该抛弃原有的主要地位, 不应该从自己出发, 提前设立教学方法, 不但要利用老师拥有的专业能 力来准备课堂内容, 而且要改变过去的以课本为基 础, 固定形式的传授流程。应该把学生放在主要地 位, 研究学生的想法, 解决学生们不能解决的障碍, 和学生们一起商讨解决问题的方法, 也要注意沟通 方式, 用真理来说服学生, 感化学生。

\section{3. 结论:}

思想政治教育不能再固守原有的落后课堂传授 方法, 而要寻求顺应时代潮流, 顺应学生心理状态 的教育方法, 让学生更好地接受思想政治知识。老 师和学生之间要连接起一条心灵纽带, 用爱来渗透 思想政治知识, 把真正实用的知识教给学生。

\section{Reference:}

[1] General Office of the Standing Committee of the National People's Congress, Literature Research Office of the Central Committee of the Communist Party of China. Selected works of the people's 
Congress system (Volume I) [g]. Beijing: China democracy and legal system press, 2015

[2] Zhu Jiao, Li Xue, Liu Tong, et al. Based on the "great ideological and political" perspective, Xi Jinping's new era of China's socialist ideology "three progressive" teaching methods research [J]. contemporary education practice and teaching research (Electronic Journal), 2018, (12): 688699.

[3] Xi Jinping stressed at the National Conference on Ideological and political work in Colleges and Universities: "Ideological and political work goes through the whole process of education and teaching, creating a new prospect for the development of higher education in China [N]. People's daily, 201612-09 (01).

[4] Xi Jinping. China wins the victory of building a welloff society in an all-round way and wins the great victory of socialism with Chinese characteristics in the new era: report on the nineteenth National Congress of the Communist Party of China [M].] Beijing: People's publishing house, 2017:41.

[5] Sun Hongli, Liu Wenyong, Huang Bizhen, Yu Tiantian. Research on the ability elements of Ideological and political education of University Graduate Students under the new media environment [J]. Journal of Shenyang University: Social Science Edition, 2017, 19 (4): $472-476$

[6] Sun Xiaofeng. Inheriting and carrying forward fine family style, cultivating and bringing up new people of the times -- Thinking and Practice on a series of activities of family style culture into campus [J]. Journal of Chizhou University, 2019,33 (4): 1-5

[7] Xiao Yonghui, Li Yanbing Xi Jinping. The educational thoughts of youth values in the new era of socialism with Chinese characteristics: [J]. Journal of Northeastern China Normal University: Philosophy and Social Sciences Edition, 2019,0 (5): 152-157.

[8] Xi Jinping. With the Central Party School Secretary of the county Party committee seminar, the students stressed that Jiao Yulu, a secretary of the county Party committee, has a sense of responsibility in the heart of the party. There is a sense of responsibility in the heart of N. Guangming Daily, 2016-01-13 (01).

[9] Wu ye, Luo Guoji. The predicament and Path Exploration of Marxism Popularization in contemporary China [J]. Journal of Inner Mongolia Agricultural University: Social Science Edition, 2011, 13 (6): 274-27

[10] Tang Li, Yan Changli, Chen Lin, long Mei, Wu Wentao. Xi Jinping's teaching strategy research on the introduction of socialism with Chinese characteristics in the new era $[\mathrm{J}] . \mathrm{J}]$. Journal of the Institute of education, China, 2019, 33 (6): 148 - 150.

[11] Du Zhixiong, Xiao Weidong. Adjusting the relationship between urban and rural areas with scientific theory and decision-making -- the Centennial exploration and practical experience of the Communist Party of China in adjusting the relationship between urban and rural areas [J]. Chinese leadership science, 2021 (2): 31-37

[12] Zheng Zili, Zhou zuohan. Analysis on the current situation of promoting the popularization of Marxism in contemporary China by colleges and Universities -- Based on the empirical investigation of ordinary undergraduate colleges and universities in Changsha [J]. Journal of Social Sciences of Hunan Normal University, 2011, 40 (2): 135-139

[13] Zhou Liang, Chen Yuanqing, Shang Jie. Xi Jinping's effectiveness in the propaganda and education of China's socialist ideology in the new era [J]. Journal of China University of Petroleum, 2019 (3): 32 - 38.

[14] Gu Hai Liang. Theoretical guidance and development concept of Ideological and political education in New Era: learning Xi Jinping's ideological and theoretical education guide in China's new era of socialism with Chinese characteristics, 2018 (1): 4 - 10., [J].

[15] Zhou Liang, Pan Hong, Wang Xin. Xi Jinping's basic principles, main ways and general train of thought in China's new era of socialism with Chinese characteristics in the ideological and political classroom [J]. Journal of Kunming University of Science and Technology (SOCIAL SCIENCES), 2019 (6): 37 - 43.

[16] Jing Weiwei, Gong Jianhua. The popularization of Marxism in the new media era -- a study of discourse transformation based on Mass Communication [J]. Journal of Bohai University: Philosophy and Social Sciences, 2017, 39 (6): 131-135 